\title{
How Information Theory Met Chemical Graph Theory in Ruder Bošković Institute
} Reminiscence for the years of collaboration with the jubilee On the occasion of the $80^{\text {th }}$ Anniversary of Prof. Dr. Nenad Trinajstić

\author{
by Danail Bonchev \\ Virginia Commonwealth University, Richmond, Virginia, USA
}

\begin{abstract}
T HE 1960s have been years of hopes and disappointments: hopes that people on both sides of the Iron Curtain will find the way to live together in peace and mutual understanding; disappointments because this had to wait twenty more years. In those turbulent times the European Summer School in Quantum Chemistry that has taken place in Herceg Novi (Montenegro) in the year 1967 was a rare oasis in which young scientists from the divided Europe could meet, discuss, learn from each other. Following the kind invitation of Dr. Milan Randić (whom I met an year earlier in a conference in Kiev) I was happy to attend this memorable school and enjoyed my contacts with young Croatian colleagues from Rudjer Bošković Institute in Zagreb. This is how I first met Nenad, a very friendly sophisticated young man. Our collaboration had to wait for some more years, in which both of us lost some of our illusions about quantum chemistry and started searching for novel approaches to theoretical chemistry. Nenad found his place in applying graph theory to analyzing chemical structures, summarizing later his experience in the excellent book "Chemical Graph Theory". ${ }^{[1]}$ My path was different. I was applying Claude Shannon's information theory to the organization of electrons and protons in atomic nuclei and electronic shells, as well as to symmetry in molecular structures (later summarized in the book "Information Theoretic Indices for Characterization of Chemical Structures"). [2]

When Nenad visited in 1975 my Higher School of Chemical Technology in Burgas, Bulgaria, I showed him my work on applying information theory to chemical structures. I'll never forget his strong encouragement after seeing my unpublished work in this new field: "Man, you MUST
\end{abstract}

publish those!". Then he invited me to Ruđer Bošković Institute for the first three months of the year 1976. The spacious office of the four theoreticians (Nenad, Ivan Gutman, Danko Bosanac and myself) offered an inspiring atmosphere with many discussions and jokes. This group of Ruđer Bošković Institute (including also Milan Randić from a distance) was the first group focusing entirely on the theory and applications of graphs theory to chemistry. This influenced me strongly for my future work. While in Ruđer, at certain point I started doing some simple calculations for the distance between atoms by counting the number of edges connecting each pair of atoms down the shortest path between them. One day Gutman looked over my shoulder for a minute and said: "Congratulation, Sir! You have just reinvented the Wiener number." This is how I become acquainted with the important papers of Harry Wiener in 1947 and 1948, which provided a powerful approach to the search for structure-property correlations of chemical compounds. Then, I combined my information theoretic approach with the Wiener metric of chemical graphs and till the end of the three months the first detailed study of molecular branching was finished. Our joint paper ${ }^{[3]}$ with Nenad appeared a year later in the Journal of Chemical Physics and it is still enjoining popularity with over 525 citations according to Google Scholar website. Thus our collaboration with Dr. Trinajstić was focused on molecular topology as described by derived relationships for the Wiener number and its information theoretic analogues. This resulted in 13 of our 17 joint publications published between the years 1977 and $1983^{[3-15]}$ in which we studied in detail molecular topology through its basic characteristics - 
branching and cyclicity. Three of the remaining four joint publications ${ }^{[16-18]}$ dealt with several quantitative structureproperty studies (QSAR). I must emphasize here the important role of my very talented formed student Prof. Dr. Ovanes Mekenyan in 12 of the joint publications with Dr. Trinajstić. The last joint paper published in the year 2001 generalized the Zagreb indices by accounting for all the subgraphs in a given molecular graph. ${ }^{[19]}$

In the 1990s the changes in this part of Europe and my emigration to the US practically interrupted our collaboration. However, we were pleased to observe the continuing interest to our joint 17 publications which till now have been cited over 1300 times according to the Scholar Google website. As for my old friend Nenad, with his more than 20000 citations according to Google Scholar, and over 11000 reads as counted by the ResearchGate website, he is in the top $2.5 \%$ of the $11+$ millions of scientists, members of this international online network.

Happy anniversary, Nenad! Mathematical chemists in the world are eagerly waiting for your future publications.

\section{REFERENCES}

[1] N. Trinajstić, Chemical Graph Theory, $2^{\text {nd }}$ ed., CRC Press 1992, pp.352.

[2] Danail Bonchev, Information Theoretic Indices for Characterization of Chemical Structures. Research Studies Press, John Wiley, 1983, pp. 249.

[3] D. Bonchev, N. Trinajstić, J. Chem. Phys. 1977, 67, 4517.
[4] D. Bonchev, N. Trinajstić, Int. J. Quantum Chem. 1978, 14(S12), 293.

[5] D. Bonchev, J. V. Knop, N. Trinajstić, MATCH 1979, 6, 21.

[6] D. Bonchev, O. Mekenyan, J. V. Knop, N. Trinajstić, Croat. Chem. Acta 1979, 52, 361.

[7] O. Mekenyan, D. Bonchev, N. Trinajstić, MATCH 1979, 6, 93.

[8] D. Bonchev, O. Mekenjan, G. Protić, N. Trinajstić, J. Chromat. A 1979, 176, 149.

[9] D. Bonchev, O. Mekenyan, N. Trinajstić, Int. J. Quantum. Chem. 1980, 17, 845.

[10] O Mekenyan, D Bonchev, N Trinajstić, Int. J. Quantum Chem. 1980, 18, 369.

[11] O. Mekenyan, D. Bonchev, N. Trinajstić, Int. J. Quantum Chem. 1981, 19, 929.

[12] D. Bonchev, O. Mekenyan, N. Trinajstić, J. Comput. Chem. 1981, 2, 127.

[13] O. Mekenyan, D. Bonchev, N. Trinajstić, MATCH 1981, 11, 145.

[14] D. Bonchev, N. Trinajstic, Int. J. Quantum Chem. Symp. 1982, 16, 463.

[15] O. Mekenyan, D. Bonchev, N. Trinajstić, Croat. Chem. Acta 1983, 56, 237.

[16] O. Mekenyan, D. Peitchev, D. Bonchev, N. Trinajstić, J. Dimitrova, Arzneim. Forsch. 1986, 36, 629.

[17] O. Mekenyan, D. Bonchev, N. Trinajstić, D. Peitchev, Arzneim. Forsch. 1986, 36(3), 421.

[18] O. Mekenyan, D. Bonchev, A. Sabljić, N. Trinajstić, Acta Pharm. Yugosl. 1987, 37, 75.

[19] D. Bonchev, N. Trinajstić, Environ. Res. 2001, 12, 213 